\title{
PLEISTOCENE UPLIFT AND PALAEOENVIRONMENTS OF MACQUARIE ISLAND: EVIDENCE FROM PALAEOBEACHES AND SEDIMENTARY DEPOSITS
}

\author{
by D.A. Adamson, P.M. Selkirk, D.M. Price, N. Ward and J.M. Selkirk
}

(with two tables and four text-figures)

Adamson, D.A., Selkirk, P.M., Price, D.M., Ward N. \& Selkirk, J.M., 1996 (xi): Pleistocene uplift and palaeoenvironments of Macquarie Island: evidence from palaeobeaches and sedimentary deposits. In Banks, M.R. \& Brown, M.J. (Eds): CLIMATIC SUCCESSION AND GLACIAL HISTORYOF THE SOUTHERN HEMISPHERE OVER THE LAST FIVEMILLION YEARS. PAP. Proc. R. Soc. Tasm. 130(2): 25-32. https://doi.org/10.26749/rstpp.130.2.25 ISSN 0080-4703. School of Biological Sciences, Macquarie University, NSW, Australia 2109 (DAA, PMS); School of Geosciences, University ofWollongong, Wollongong, NSW, Australia 2522 (DMP); Australian Surveying and Land Information Group, Belconnen, ACT, Australia 2616 (NW); and Graduate School of the Environment, Macquarie University, NSW, Australia 2109 OMS).

Macquarie Island $\left(54^{\circ} 30^{\prime} \mathrm{S}, 159^{\circ} 00^{\prime} \mathrm{E}\right)$ is an emergent part of the Macquarie Ridge Complex composed of ocean-floor rocks of Miocene age now $4000 \mathrm{~m}$ above the ocean floor. A number of landforms, including palaeobeaches now above sea level (a.s.l.) on Macquarie Island, were formed by marine erosion during uplift of the island. During the last Pleistocene period of low sea level (c. $20 \mathrm{ka}$ ) the island was three times larger than now. Thermoluminescence (TL) dating of two palaeobeaches indicates Pleistocene ages: $172 \pm 40 \mathrm{ka}$ for one at $100 \mathrm{~m}$ a.s.l. and $340 \pm 80 \mathrm{ka}$ for another at $263 \mathrm{~m}$ a.s.l. Matching the altitude sequence of palaeobeaches on Macquarie Island with the pattern of peaks in world sea level determined from deep sea cores allows an independent estimate of beach ages. Comparison of the altitude and sea level sequences most plausibly places the $100 \mathrm{~m}$ palaeobeach in Oxygen Isotope Stage 5e (130-125 ka) and the $263 \mathrm{~m}$ palaeobeach in Stage 9 (340-330 ka), matching reasonably with the TLdates. Other palaeobeaches at about $50 \mathrm{~m}$ and $170-190 \mathrm{~m}$ a.s.l. then correlate with high sea levels. We calculate an average rate of uplift for the island of $0.8 \mathrm{mma}^{-1}$. At this rate, $4000 \mathrm{~m}$ of Macquarie Ridge uplift would have taken about five million years and the top of the island may first have emerged some 700 to $600 \mathrm{ka}$. During the six Pleistoceneglacialinterglacial cycles since then, there has been periglacial rather than glacial activity on cold uplands, but conditions suitable for vegetation of the present type persisted close to sea level.

Key Words: Macquarie Island, Macquarie Ridge, uplift, raised beaches, palaeobeaches, thermoluminescence dating, Pleistocene, subantarctic.

\section{INTRODUCTION}

Macquarie Island and its associated islets, at about $54^{\circ} 30^{\prime} \mathrm{S}$ and $159^{\circ} 00^{\prime} \mathrm{E}$, are the only emergent parts of the submarine Macquarie Ridge Complex (MRC) at the boundary of the Pacific and Australian tectonic plates. The MRC is a submarine mountain range rising over $4000 \mathrm{~m}$ above the sea floor. It extends south from New Zealand for over $2000 \mathrm{~km}$ to the mid-ocean spreading ridge that encircles Antarctica. It is subdivided by deep transverse valleys and flanked by a series of deep trenches. To the north, the MRC is linked to the New Zealand Alpine Fault by a zone of strike-slip faults (Collot et al. 1995). Details of its southern connection to the mid-ocean spreading ridge are not well known. Information about the MRC in the vicinity of Macquarie Island has been obtained recently from a cruise of the R/V Rig Seismic (Coffin et al. 1994). Although not yet fully analysed, the results show an active deformation zone a few tens of kilometres wide, termed the Macquarie Fault Zone (MFZ), usually on the crest or on one side or the other of the MRC and flanked by fracture zones which asymptotically merge with the MFZ.

The MFZ is an extremely active deformation zone, with righr-lateral strike-slip movement and some convergence between the Pacific and Australian plates. Severe shallow earthquakes are common, including the magnitude 8.2 earthquake of 1989 (Ruff 1990 and associated papers), now believed to have occurred on the MFZ (Coffin et al. 1994). Earthquakes of magnitude 6 or more are recorded near Macquarie Island annually (Jones \& McCue 1988: fig. 3).
Macquarie Island (and the ridge of which it forms the crest) is tectonically uplifted sea-floor material formed during the Miocene (Duncan \& Varne 1988). Raised marine beaches (Varne et al. 1969, Ledingham \& Peterson 1984) provide direct evidence of uplift, as does the ocean-floor geology of the island (Varne \& Rubenach 1972). The island is thought by Colhoun \& Goede (1973) to have emerged above sea level (a.s.l.) in the mid or late Pleistocene, based on extrapolation of uplift rates determined from marine deposits raised about $9 \mathrm{~m}$ above present high water level and dated as mid to late Holocene $(6-2 \mathrm{ka})$. Ledingham \& Peterson (1984) suggest a late Quaternary emergence.

This paper presents new evidence for the time at which Macquarie Island emerged, for its uplift rate and, hence, for uplift of the MRC in its vicinity. Two lines of evidence are considered: direct dating of raised beaches by the thermoluminescence (TL) method, and cross-matching of the world sea-level sequence during the mid to late Pleistocene with the altitudinal sequence of beaches that are thought to have been formed by marine action during previous times of high sea level. Implications for the palaeoenvironment of the island are also considered.

\section{ISLAND AND RIDGE MORPHOLOGY}

Macquarie Island is a steep-sided mountainous plateau $200-400+m$ a.s.l., rising from a gently sloping platform cut during marine transgressions following the periods of worldwide low sea level (Adamson et al. 1988). This platform extends offshore on all sides of the island to a depth of at least 
$100 \mathrm{~m}$ : to the west it is $2-4 \mathrm{~km}$ wide, on the east it is narrower, while to the north and south, it extends at least $30 \mathrm{~km}$. The offshore small islands (fig. 1) also rise from this platform, which is roughly $100 \mathrm{~km}$ long by $10 \mathrm{~km}$ wide.

This platform is the planed-off crest of the main ridge, with the islands as sea-trimmed remnants of higher land. Figure 2 shows that the original form of the crest of the ridge before wave erosion was probably convex and not much higher than the present highest peaks on Macquarie Island. It also shows, to the west, a parallel but slightly lower submarine ridge with a smoothly convex crest. We infer that this ridge has not been exposed to wave erosion, even during periods of low sea level in the glacial cycles of the Pleistocene. Although published bathymetric data for the area west of Macquarie Island are sparse and poorly controlled, they allow us to propose that the undersea western ridge is an analogue for the pre-emergence shape of the $100 \mathrm{~km}$ long part of the eastern ridge from which the islands now emerge.

Above present sea level on Macquarie Island are landforms, such as raised beaches and subhorizontal benches that slope gently seawards, which are interpreted as having been formed or influenced by marine erosion at the sea surface when global sea levels fluctuated during glacialinterglacial cycles. In this paper, we consider raised beaches but not the benches, because their altitudes are poorly defined. The topographic map (Division of National Mapping 1971) has $50 \mathrm{~m}$ contour intervals rather inaccurately located (Selkirk \& Adamson 1995). We have concentrared on palaeobeaches, particularly those for which we have determined altitude by differential global positioning system (DGPS). Heights of beaches given by Ledingham \& Peterson (1984), in their excellent survey of raised beaches on the island, are not used, since their altitudes depend in part on unreliable contours and spot heights. Further topographic mapping of the island presently being carried out will allow an improved analysis of all raised beaches and benches.

\section{THERMOLUMINESCENCE DATING OF TWO RAISED BEACHES}

Two palaeobeaches were selected for dating and accurate height determination (fig. 3). Both are composed only of rounded clasts and occupy topographic high points, so that contamination from above is unlikely. The first, at $263 \pm 5 \mathrm{~m}$ (DGPS) a.s.l., is at or near Beach 2 (Scoble Lake Beach) of Ledingham \& Peterson (1984). It caps the eastern half of the subhorizontal ridge oriented NW-SE which forms the watershed between Hasselborough Bay and the extensive shallow basin containing Scoble Lake and numerous smaller lakes. Scoble Lake (214-215 m a.s.l.: DGPS) is almost $50 \mathrm{~m}$ lower than the palaeobeach on the ridge and roughly $750 \mathrm{~m}$ distant. In addition, other deposits of highly rounded cobbles occur southwards as far as Island Lake (Beach 4 of Ledingham $\&$ Peterson 1984) and beyond. To avoid confusion, we refer to the $263 \mathrm{~m}$ beach as Hasselborough Palaeobeach (fig. 3). The second palaeobeach selected, Wireless Hill Palaeobeach, is on the west side of the flat-topped Wireless Hill, close to the altitude of the base of Mawson's radio mast (102.8 $\pm 0.3 \mathrm{~m}$ a.s.l.: DGPS) and on a different tectonic fragment of the island (Duncan \& Varne 1988). This is Beach 1 of Ledingham \& Peterson (1984). Rounded cobbles are also exposed on the northeastern edge of the Wireless Hill

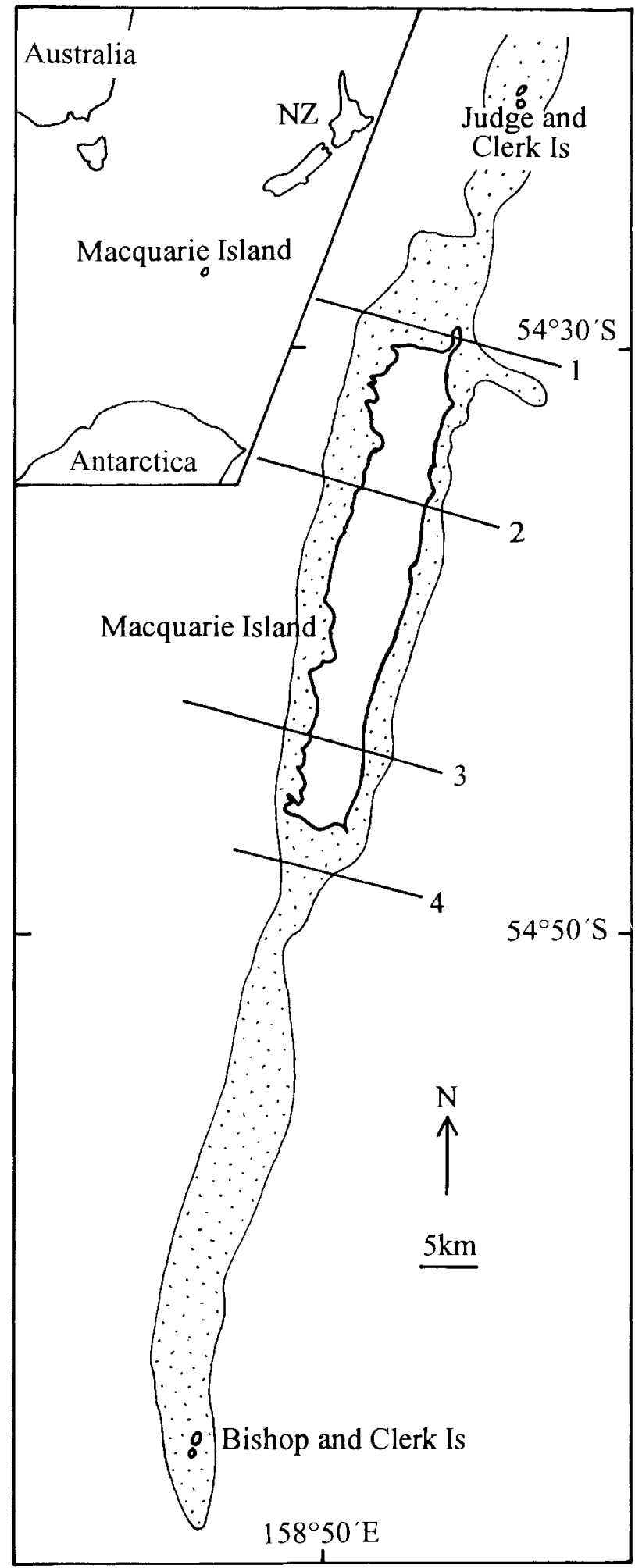

FIG. I - Macquarie Island and adjacent islets, shallow sea floor less than $150 \mathrm{~m}$ deep (stippled) and location of numbered sections (fig. 2) across part of the Macquarie Ridge System.

plateau at the same altitude. The whole of Wireless Hill was planed by marine erosion.

The beaches and orher sedimentary deposits on Macquarie Island are difficult materials for TL dating. The rocks are a sea-floor suite, including pillow lavas, sheeted dykes, gabbro, serpentinite and harzburgite. Volcanic materials have been successfully dated elsewhere (Guérin \& Balladas 


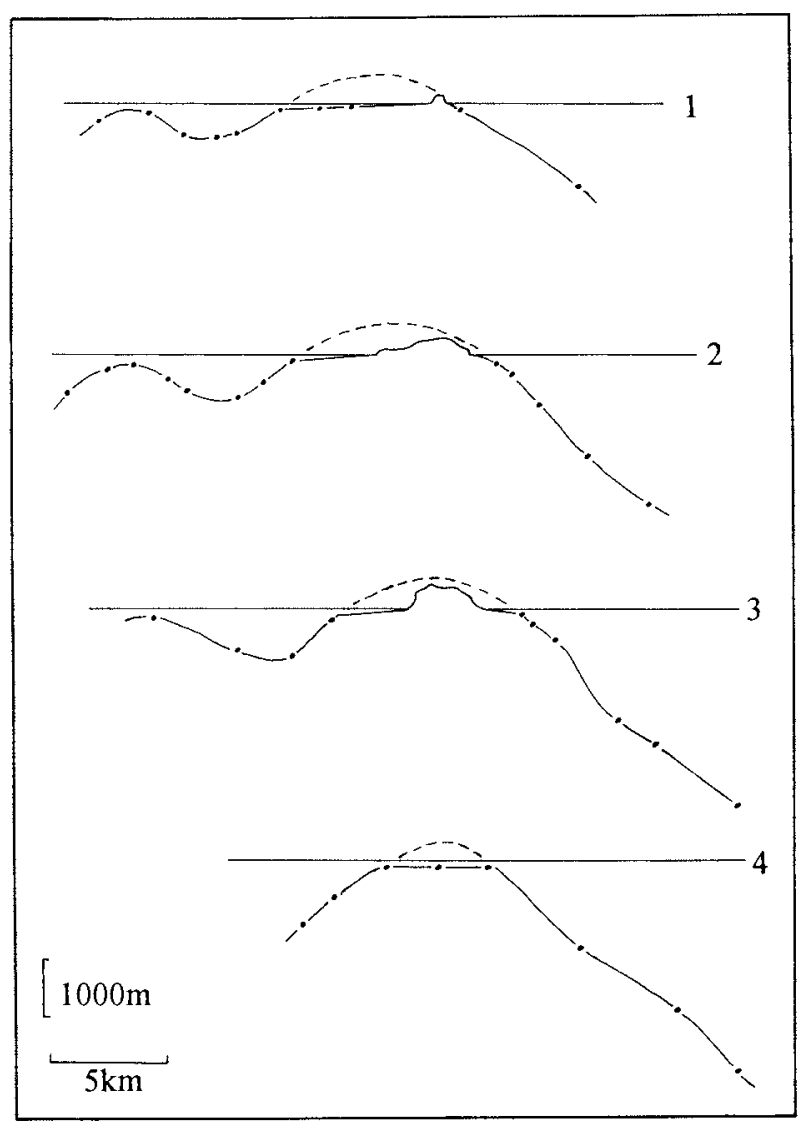

FIG. 2 - Four sections (location, fig. 1) across Macquarie Island and adjacent sea floor. Section 1 through Wireless Hill; section 2 through Mt Tulloch; section 3 through Mt Fletcher; section 4 approximately $5 \mathrm{~km}$ south of island. Dots represent depths taken from bathymetric information of the Royal Australian Navy Hydrographic Office; dashed line shows a reconstruction of the ridge crest at Macquarie Island before its emergence above sea level.

1980). The Macquarie Island samples had low TL sensitivity and low radioactivity, contributing to the large value of the standard deviation (SD) of the dates obtained (table 1). Despite the insensitivity of the samples and the very large SD, the dates show that the two palaeobeaches are Pleistocene in age and of the order of one hundred to several hundred thousand years old. Secondly, the two palaeobeaches are in an age sequence matching their altitudinal position, that is the higher beach is older. From these $T L$ dates, we consider it reasonable to allocate age ranges between 200 and 100 thousand years to the $100 \mathrm{~m}$ Wireless Hill Palaeobeach and between 400 and 300 thousand years to the $263 \mathrm{~m}$ Hasselborough Palaeobeach. A lacustrine deposit (fig. 3) on the plateau northeast of Bauer Bay was also dated. It is younger than both beaches and probably formed in the early half of the last glacial cycle between Oxygen Isotope Stage 4 and the middle of Stage 5.

Greater accuracy is difficult to achieve with these samples, given their relative insensitivity to the TL method. The dates do, however, bracket the ages of deposition of the two palacobeaches, which are separated in altitude by over $150 \mathrm{~m}$.

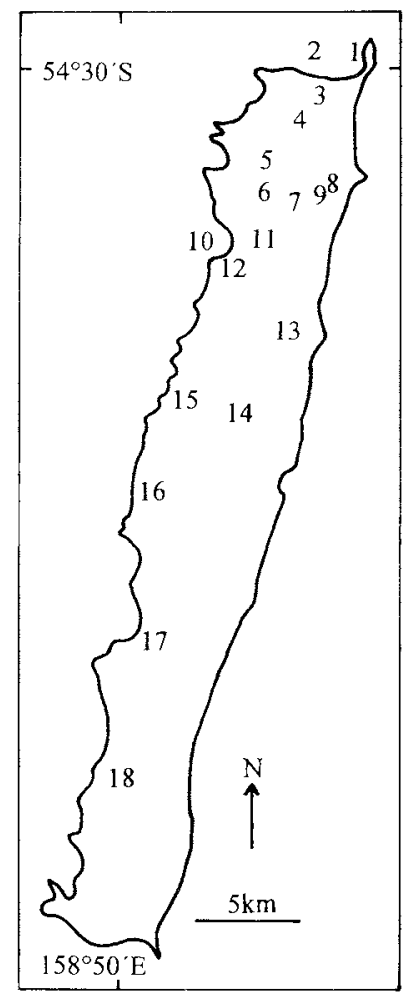

FIG. 3 - Macquarie Island, location of features mentioned in the text: 1, Wireless Hill Palaeobeach; 2, Hasselborough Bay; 3, Hasselborough Palaeobeach; 4, Scoble Lake; 5, Island Lake; 6, Lacustrine deposit, exposed in bank of North Bauer Creek on plateau northeast of Bauer Bay; 7, Mt Power; 8, Rookery Creek; 9, Mt Elder; 10, Bauer Bay; 11, palaeobeaches on plateau above Bauer Bay and near Emerald Lake; 12, Gentoo Flat Palaeobeach; 13, Mt Tulloch; 14, Mt Eitel; 15, Gully on western edge of plateau, west of Mt Eitel; 16, Mt Waite, 17, Major Lake Palaeobeach; 18, Mt Fletcher.

\section{CROSS-MATCHING THE TIMING OF HIGH GLOBAL SEA LEVELS WITH THE ALTITUDE OF PALAEOBEACHES}

A method of estimating the time of formation of raised marine features, which is independent of direct dating techniques, is to determine accurately the altitudes of the raised beaches and to match the resulting al titudinal sequence against the patterns of peaks of worldwide sea level, determined from deep sea cores. As previously noted, a problem with this approach is to determine accurately altitudes of the palaeobeaches. DGPS measurements have been used for the purpose. The approach assumes that palaeobeaches formed at periods of high global sea level and were preserved because subsequent tectonic uplift raised them above later marine transgressions. Studies of raised beaches and platforms on rising coasts assume their formation during interglacial and interstadial times of eustatically high sea level (Bradley \& Griggs 1976, McInelly \& Kelsey 1990). A second assumption is that the frequency, amplitude and dating of the smoothed stack of marine oxygen isotope curves of Imbrie et al. (1984) can be applied to Macquarie Island and, further, that the most recent postglacial sea-level rise at the island was about 
TABLE 1

Thermoluminescence dates*, Macquarie Island

\begin{tabular}{llll}
\hline Specimen No. & W1620 & W1621 & W1622 \\
Location & North Bauer Creek & Wireless Hill & Hasselborough \\
Plateau region $\left({ }^{\circ} \mathrm{C}\right)$ & $325-375$ & $300-400$ & $275-325$ \\
Analysis Temp. $\left({ }^{\circ} \mathrm{C}\right)$ & 375 & 350 & 325 \\
Palaeodose (Grays) & $79 \pm 16$ & $92 \pm 19$ & $156 \pm 32$ \\
$\mathrm{k}_{\mathrm{T}}$ (alpha/beta TL eff) & $0.143 \pm 0.028$ & $0.107 \pm 0.022$ & $0.094 \pm 0.019$ \\
$\mathrm{~K}$ content (\% by AES) & $0.225 \pm 0.005$ & $0.100 \pm 0.005$ & $0.140 \pm 0.005$ \\
Moisture content (\% weight) & $24.2 \pm 3$ & $7.8 \pm 3$ & $19.0 \pm 3$ \\
Specific activity (Bg/kg U + Th) & $13.9 \pm 0.4$ & $7.2 \pm 0.2$ & $5.6 \pm 0.2$ \\
Annual Radiation Dose $(\mu \mathrm{Gy} / \mathrm{yr})$ & $853 \pm 85$ & $532 \pm 53$ & $460 \pm 46$ \\
TL Age (ka) & $92 \pm 20$ & $172 \pm 40$ & $340 \pm 80$ \\
\hline
\end{tabular}

* Based on the method as described by Airken (1985) using the 1-8 micrometre polymineral grain-size fraction. Assumed Rb content: $50 \pm 25 \mathrm{ppm}$; assumed cosmic contribution $150 \pm 50 \mu \mathrm{Gy} / \mathrm{yr}$

$125 \mathrm{~m}$. The assumption is also made that the beaches preserved on the island represent the major transgressions of the middle and late Quaternary, and that none are missing, with the partially exposed marine terrace close to present sea level representing the postglacial transgression between about 18 and $6 \mathrm{ka}$ (Adamson et al. 1988, Selkirk, P.M. et al. 1990a). As we know of 17 raised beaches between $50 \mathrm{~m}$ and $260 \mathrm{~m}$ a.s.l. on Macquarie Island, we assume that the major episodes of late Pleistocene high sea level are represented by topographic features in our data set.

Figure 4 shows the cross-matching obtained when (1) the altitude (vertical) scale is set by assuming a post-last glacial sea level rise of $125 \mathrm{~m}$; and (2) the $100 \mathrm{~m}$ Wireless Hill Palaeobeach is assumed to have been formed at the last interglacial high sea level of $125 \mathrm{ka}$ (Sub-stage 5e). Beaches below and above the Wireless Hill Palaeobeach are then related in sequence to sea-level peaks.

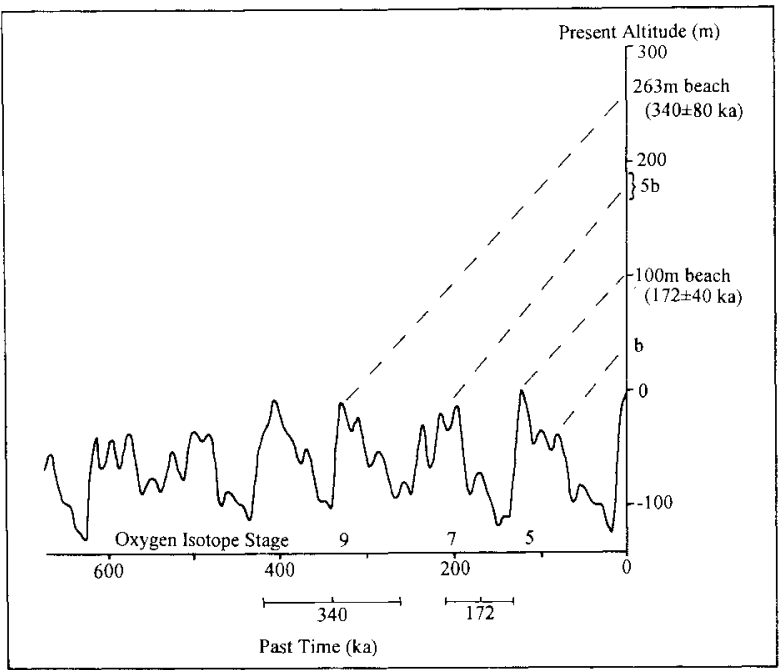

FIG. 4 - Cross-match of altitudes of palaeobeaches to high sea-level peaks of $\delta^{18} \mathrm{O}$ sea-level curve (Imbrie et al. 1984), shown by dashed lines. TL dates for two palaeobeaches are shown on each axis. The highest mountains around $400 \mathrm{~m}$ a.s.l. may have first emerged about $600 \mathrm{ka}$. At least five palaeobeaches (5b) cluster between about 170 and $190 \mathrm{~m}$, and one palaeobeach (b) is at about $50 \mathrm{~m}$ a.s.l.
Table 2 compares the match shown in figure 4 with two other possible ways of cross-matching the altitudes of marine palaeobeaches with the times of high sea level. Neither provides as satisfactory a match between the altitude of the palaeobeaches on the island and odd numbered (interglacial) oxygen isotope stages. In addition, figure 4 shows that the preferred cross-matching provides a reasonable accord with the TL dates. The Hasselborough Palaeobeach $(263 \mathrm{~m})$ is allocated by cross-matching to Stage 9 , and the TL date of $340 \pm 80 \mathrm{ka}$ supports this. The TL date (172 $\pm 40 \mathrm{ka})$ for the Wireless Hill Palaeobeach $(100 \mathrm{~m})$ is less satisfactory, as Sub-stage 5e lies at the younger edge of the TL uncertainty level. However, bearing in mind the low TL sensitivity of the samples, TL dating and cross-matching, based on allocating the $100 \mathrm{~m}$ beach to Sub-stage 5e, support each other. If other assumptions are used as the basis for crossmatching (table 2), no relationship to the TL dates is apparent.

\section{UPLIFT OF MACQUARIE ISLAND AND THE MACQUARIE RIDGE}

Allocation of ages (fig. 4) to the raised beaches allows average rates of uplift to be estimated during the period the crest of the ridge has been above sea level. Because of the long time involved, uplift values are averaged over tens to hundreds of thousands of years. The slopes of the lines on figure 4 , joining peaks on the sea-level curve with palaeobeaches, represent uplift rates. The approximately parallel slopes suggest fairly uniform uplift for the last half million years, at an average rate of c. $0.8 \mathrm{mma}^{-1}$.

This average uplift rate for the last half million years of the Pleistocene is between one-half and one-sixth of the rates calculated from Holocene marine deposits, summarised by Selkirk, P.M. et al. (1990b). The calculations of Holocene rates were based on rocks formed 6 to $2 \mathrm{ka}$, uplifted by no more than $10 \mathrm{~m}$ above present sea level. As the estimates of Pleistocene uplift now presented are based on deposits well over an order of magnitude higher and older than the Holocene deposits, we consider the agreement between Holocene and Pleistocene estimates reasonable, particularly as the long-term average rate would conceal pulses of uplift.

The one Holocene uplift rate that stands out as remarkably different is the rate of $14.5 \mathrm{mma}^{-1}$ for Wireless Hill. The 
TABLE 2

Comparison of three ways of cross-matching the present altitudes of palaeobeaches on Macquarie Island with times of high sea level

\begin{tabular}{|c|c|c|c|c|c|c|c|}
\hline \multicolumn{2}{|l|}{ Palaeobeach } & \multicolumn{6}{|c|}{$\begin{array}{l}\text { Calculated age }(\mathrm{ka}) \text { and marine isotope stage } \\
\text { ( } 125 \mathrm{ka} \text { age assumed for the beaches) }\end{array}$} \\
\hline \multirow[t]{2}{*}{ Location } & \multirow{2}{*}{$\begin{array}{l}\text { Present } \\
\text { altitude }(\mathrm{m})\end{array}$} & \multicolumn{2}{|c|}{$50 \mathrm{~m}$} & \multicolumn{2}{|c|}{$100 \mathrm{~m}$} & \multicolumn{2}{|c|}{$170-180 \mathrm{~m}$} \\
\hline & & ka & Stage* & $\mathrm{ka}$ & Stage* & $\mathrm{ka}$ & Stage* \\
\hline Gentoo Flat & c. 50 & 125 & $5 \mathrm{e}^{\ddagger}$ & 63 & 3 & 36 & 2 \\
\hline Wireless Hill & $100^{\dagger}$ & 250 & 7 & 125 & $5 e^{\ddagger}$ & 71 & 4 \\
\hline \multicolumn{8}{|c|}{ Bauer Bay-Emerald } \\
\hline Lake area & c. $170-180$ & $425-450$ & $11-12$ & $215-225$ & 7 & 125 & $5 e^{\ddagger}$ \\
\hline Major Lake & c. $190^{+}$ & 475 & 13 & 238 & 7 & 136 & 6 \\
\hline Hasselborough & $263^{\dagger}$ & 658 & 18 & 329 & 9 & 188 & 7 \\
\hline
\end{tabular}

* Odd-numbered Isotope Stages represent high sea levels (interglacials), and even numbered stages periods of lower sea level. Oxygen Isotope Stages and dates after Imbrie et al. (1984).

* Altitude determined by DGPS.

Assumed.

rate was calculated by assuming that the dated pear now overlying the $100 \mathrm{~m}$ palaeobeach reflected the end of marine action at the site (Selkirk et al. 1983). We now consider that a substantial time gap existed between the time of formation of the beach and the deposition of the overlying peat at $4880 \pm 90 \mathrm{yr}$ BP (SUA-1527), so that this anomalously high rate is wrong. This is the beach, which, if assumed to be $125000 \mathrm{yr}$ in age, produces the best crossmatching of the other raised marine features to the sealevel curve (fig. 4 , table 2). In addition, the TL date for the palaeobeach suggests an age between 100 and 200 thousand years. We now interpret Wireless Hill as being uplifted along with the rest of Macquarie Island, at a long-term average rate of about $0.8 \mathrm{mma}^{-1}$.

The Macquaric Island average uplift rate of $0.8 \mathrm{mma}^{-1}$ is reasonable in relation to other tectonically active regions around the rim of the Pacific plate. Late Quaternary beaches on the Pacific coast of Oregon, USA, have been uplifted between 0.5 and $1.5 \mathrm{mma}^{-1}$ for at least $100000 \mathrm{yr}$ (McInelly \& Kelsey 1990, Muhs et al. 1990), while raised beaches on the central Californian coast of the USA have been uplifted at rates of about $0.2 \mathrm{mma}^{-1}$ for the last million years or longer (Bradley \& Griggs 1976). Uplift of the New Zealand southern highlands (Kamp et al. 1992) is similar to or faster than the Pleistocene rate for Macquarie Island.

The average rate of tectonic uplift $\left(0.8 \mathrm{mma}^{-1}\right)$ obtained over the last $500000 \mathrm{yr}$ for the $433 \mathrm{~m}$ high island can be applied to that part of the MRC of which Macquarie Island is the crest (fig. 2). To do so involves an extrapolation over one order of magnitude of vertical uplife, taking the ridge as rising approximately $4000 \mathrm{~m}$ above the ocean floor and the island as about $400 \mathrm{~m}$ a.s.l. If the rate of $0.8 \mathrm{mma}^{-1}$ is applied throughout the time of uplift of the ridge at Macquarie Island, then ridge uplift began about $5 \mathrm{Ma}$. Figure 1 suggests that the $100 \mathrm{~km}$ long ridge crest in shallow water, between at least Judge and Clerk Islands to the north and Bishop and Clerk Islands to the south, has behaved as a coherent block with Macquarie Island and the islets being those parts of the ridge crest that survived marine erosion. Major gaps occur transverse to the MRC (Gordon 1972) and it is likely that the ridge segment between these transverse gaps north and south of Macquarie Island is a tectonic unit subject to coherent uplift.

An age of about 5 million years (late Miocene-early Pliocene) for the present and major phase of uplift of the $\mathrm{MRC}$ at Macquarie Island matches fairly well with what is known of the present phase of interaction berween the Pacific and Australian plates. For example, the present major pulse of uplift of the New Zealand Alps began (or accelerated) towards the end of the Miocene at 7 to $5 \mathrm{Ma}$ (Kamp et al. 1989, 1992). In the Melanesian region along the complex northeastern edge of the Australian plate, the Woodlark Basin has been opening progressively by rifting and sea-floor spreading westwards towards New Guinea since 6 to $3.5 \mathrm{Ma}$ (Weissel et al. 1982, Benes et al. 1994, Taylor et al. 1995); Pliocene to recent volcanoes have erupted onto the Miocene basement of sedimentary rocks in the New Ireland Basin on the adjacent edge of the Pacific Plate (Herzig et al. 1994); near the Tonga Trench, the Lau Basin has been opening since about $6 \mathrm{Ma}$, initially by basin-and-range type rifring and, since about $4 \mathrm{Ma}$, by sea-floor spreading (Bevis et al. 1995). These examples around the southwestern rim of the Pacific plate north of New Zealand imply that Pacific plate movement style has been unchanged for the last few million years, as suggesced by Cox \& Embretson (1985), Pollitz (1986) and Harbert \& Cox (1989). Clearly, however, much more information is needed about the geology and palaeomagnetics of the sea floor in the southern Pacific (Acton \& Gordon 1994).

Although the roughly $100 \mathrm{~km}$ ridge segment that includes Macquarie Island was probably uplifted as a coherenc block, the island is cut by numerous faults and linear scarps that undoubtedly mark the location of faults. About 200 such features are known (Ledingham \& Peterson 1984, Selkirk, P.M. et al. 1990b, Adamson et al. 1993) and many are still active. We conclude that the net effect of movements on such faults is small compared with displacement that forces up the whole block. Faulting within the island, while active, seems not to have destroyed the age-height relationships of the beaches considered in this paper. Many of the vertical displacements are only a few metres. For example, the Hasselborough Palaeobeach is crossed by at 
least two faults, which have divided the original beach into three benches only a few metres apart vertically. The dated material came from the highest level. During uplift, this beach and the Wireless Hill Palaeobeach have remained subhorizontal, suggesting little or no tilting during more than $250 \mathrm{~m}$ of uplift over the last 300 to 400 thousand years. The eastward dip of some volcanic units and faulted contacts between some of the rock units (Varne \& Rubenach 1972, Duncan \& Varne 1988) probably reflect earlier events.

\section{PLEISTOCENE ENVIRONMENTS}

If our estimate of age is correct, Macquarie Island has been above sea level for at least six glacial-interglacial cycles, yet there is little or no evidence of glacial landforms on the island (Ledingham \& Peterson 1984, Adamson et al. 1988). However, Mawson (1943), Colhoun \& Goede (1974), Löffler \& Sullivan (1980) and Crohn (1986) have taken a different view and considered that glaciation affected much or all of the present plateau. Colhoun later considered that "previous records of glaciation now seem quite uncertain..." (in Selkirk, P.M. et al. 1990b: 79). Features previously described as erratics, moraines, kame terraces, overdeepened lakes, meltwater channels, glacial valleys and cirques on the island have turned out to be explicable as topographic expressions of faulting and non-glacial erosion. Even the large semicircular amphitheatre of Rookery Creek north of Mt Elder, which is usually interpreted as a glacial cirque (Colhoun \& Goede 1974, Crohn 1986) can be better explained as a valley whose margin and shape are determined by curving faults rather than by mobile ice. This view is strengthened by the presence of a palaeobeach at $259 \mathrm{~m}$ a.s.l. (DGPS) within the amphitheatre, and by the presence of many minor faults such as those exposed in the gully of Rookery Creek.

The one remaining plausible line of evidence for glacial action is the presence in localised places of polished and scratched cobbles, sometimes embedded in blue clay (Mawson 1943). From extensive sampling, we note that the polished and scratched rocks are soft and can be scratched and carved with a steel knife. Rock types include slickensided serpentinite, with additional surface polish and superimposed scratches, and harzburgite. The blue clay does not require glacial action for its formation. Crushing of soft ulrramafic rocks in fault planes to form gouges is an alternative explanation. Scratching and polishing of soft rock fragments could also occur in active fault planes, accounting for the co-occurence of cobbles and clay in a few places. Slow downslope movement of soft rocks also could produce scratching and possibly some subrounding and polishing. Mass movement of slope deposits under saturated freeze-thaw conditions of a periglacial rype occurs today and would have been more active during colder periods. We do not regard mobile ice as necessary for the formation of the polished and scratched soft cobbles and blue clays. If glacial action were to be accepted as the explanation of striated cobbles and clay, the problem remains: where are the other geomorphic manifestations of dynamic ice movement, particularly as the island is festooned with raised beaches, some of which appear to have survived several glacial cycles?

During past glacial periods, the atmosphere and oceans were colder than at present and global sea level was lower.
Temperatures during worldwide glacial times on Macquarie Island are not known, but they were probably in the range of $5^{\circ}-10^{\circ} \mathrm{C}$ lower than the present temperatures (mean $4.9^{\circ} \mathrm{C}$, mean min. $2.9^{\circ} \mathrm{C}$, mean max. $6.3^{\circ} \mathrm{C}$ ). The lower sea level of glacial times at Macquarie Island would also have caused an adiabatic cooling of about $1{ }^{\circ} \mathrm{C}$ at any present site, but new sites near sea level would have been exposed all around the island, particularly to the north and south (figs 1, 2).

Mass movement due to freeze-thaw processes is active to-day on the uplands, especially to the west of Mt Elder, and would have been more active during glacial periods. Several deposits which we interpret as periglacial are exposed in gully walls, particularly along the edges of the plateau (fig. 3). One section, west of Mt Eitel, reveals rounded beach cobbles at the base, overlain by a dense peat dominated by freshwater diatoms, in turn overlain by a thick deposit of sub-angular matrix-supported cobbles, capped by a thick sandy peat with present-day vegetation. The age of the compressed diatomaceous peat was beyond the range of radiocarbon dating (SUA 3045 and Beta-57317), i.e. greater than 40000 yr. Further dating and altitude determination will be attempted at this site, but the pre-Holocene subangular cobbles are younger than the beach (roughly $250 \mathrm{~m}$ altitude), which we infer to have been formed at abour $300 \mathrm{ka}$. The cobble deposit is thought to have been transported by mass movement from the nearby slopes on the western side of Mt Eitel, probably under periglacial climatic conditions sometime during the last three glacial cycles.

Study has also begun on a second deposit of sub-angular cobbles of possible periglacial origin that moved westward down the slopes of the Mt Power uplands into the valley of a creek (North Bauer Creek) flowing southwards via a waterfall into Bauer Bay (table 1, fig. 3). Beneath more than $2 \mathrm{~m}$ of thick blocky deposit, $1 \mathrm{~m}$ of finely laminated silts, containing sparse freshwater diatoms and scattered angular pebbles, is exposed in the gully wall. The silts have a TL date of $92 \pm 20 \mathrm{ka}$, well within the last glacial cycle. The laminated sediment, sparse diatoms and low organic content suggest deposition in an oligotrophic lake supplied with abundant silt from a relatively bare catchment, with seasonal or episodic silt input, and possibly some freezing of the lake surface to account for the scattered distribution of angular pebbles within the laminae. The overlying deposit of sub-angular cobbles is the distal end of a sheet of coarse material from the western slopes of Mt Power. The sheet is now incised by streams, with no mass movement at its downslope end. It is interpreted as a periglacial mass flow of coarse debris that overrode the lacustrine silts during the last glacial, at some time between about $90 \pm 20 \mathrm{ka}$ and the Holocene. Much work remains to be done on these and the other Pleistocene deposits on Macquarie Island.

In global glacial periods, periodic warming and abundant rain may have prevented the multi-decadal accumulation of perennial snow needed to initiate glacier-scale ice movement on the island. Nivation hollows exist today, often linked to areas of groundwater emergence by seepage or springs. Erosion associated with major snow patches would have been important in the cooler past, for example, around the rim of the semicircular valley of Rookery Creek. Mass movement by periglacial activity was probably intense at the coldest periods, and the landforms produced included mantles and gully-fills of angular to sub-angular cobbles and finer sediment. 
Because of the expansion in area of land close to sea level during cold periods of glacial cycles, we consider that plant species then on the island would have survived the lower temperatures, more abundant snow and more active erosion on the uplands by occupying low-lying land. This involves only short distances of migration horizontally (between less than one and a few kilometres) and vertically (between ten and several hundred metres). For example, the cushion plant Azorella macquariensis, now most common on the uplands of the plateau, is also abundant in suitable locations near sea level, such as at about $40 \mathrm{~m}$ a.s.l. in Bauer Bay, on rocky creek terraces where it cannot be shaded out by competitors, and on rock stacks along parts of the east coast only a few metres a.s.l. On the uplands, feldmark would have been more extensive, probably descending to as low as $50-100 \mathrm{~m}$ above the sea level of the time, especially at sites exposed to wind. The highest levels of the island may have been essentially devoid of higher plants and even feldmark mosses, with bare gravel surfaces colonised by tiny obscure plants such as the liverwort Jamesoniella colorata. Such communities exist today on extremely exposed uplands.

As habitats close to sea level would have been refugia which supported plants through past glacial cycles, the flora did not have to re-establish itself on the island after each global glacial interval. Postglacial marine transgressions did flood low-altitude refugia, but climatic warming allowed plants to move uphill, as the altitudinal limit for growth of particular species rose. Changing conditions, both climatic and topographic, may have aided the establishment of immigrant species.

Postglacial transgression also carved new landforms, since marine erosion of the top of the Macquarie Ridge was most acrive at postglacial times when sea-level rise was much faster than tectonic uplift. During these times a new marinecut terrace or platform was carved below the former one and parts of the plateau edge were eroded. Severe erosion of the plateau continued during interglacial periods of high sea level when the ocean continued to attack the base of cliffs or steep slopes, as occurs today along most of the south coast of the island. Not only the uplands of Macquarie Island but also its present coastline and its shallow offshore topography can be interpreted by taking account of the interplay between oscillating global sea levels and uplift of the Macquarie Ridge and its island over at least the last half million years.

\section{ACKNOWLEDGEMENTS}

We would like to thank the Australian Antarctic Division for logistic support; Tasmanian Parks and Wildlife Service, Deparment of Environment and Land Management for permission to work on Macquarie Island; Antarctic Science Advisory Committee Grants Scheme, Australian Research Council Grants Scheme and Macquarie University Research Grants Scheme for financial support. We thank Dr T.P. McBride for diatom analysis of the west Mt Eitel deposit, Mr A. Cox of the New Zealand Department of Conservation for assistance in the field, Mr G. Copson and Professor F. Wu for valuable discussions.

\section{REFERENCES}

ACTON, G.D. \& Gordon, R.G., 1994: Palaeomagnetic tests for Pacific plate reconstructions and implications for motion between hot spots. Science 263: 1246-1254.

Adamson, D.A., Selkirk, P.M. \& Colhoun, E.A., 1988: Landforms of aeolian, tectonic and marine origin in the Bauer Bay-Sandy Bay region of subantarctic Macquarie Island. Pap. Proc. R. Soc. Tasm.122(1): 65-82.

Adamson, D.A., Selkirk, J.M. \& Serpelt, R.D., 1993: Serpenrinite, harzburgite, and vegetation on subantarctic Macquarie Island. Arct. Alp. Res. 25(3): 216-219.

AITKEN, M.J., 1985: THERMOLUMINESCENCE DATING, STUDIES IN ARCHAEOLOGICAL SCIENCE. Academic Press, London.

Benes, V., SCOTT, S.D. \& BinNS, R.A., 1994: Tectonics of rift propagation into a continental margin: western Woodlark Basin, Papua New Guinea. J. Geophys. Res. 99(B3): 4439_ 4455.

Bevis, M., Taylor, F.W., Schutz, B.E., Recy, J., Isacks, B.L., Helu, S., Singh, R., Kendrick, E., Stowell, J., Taylor, B. \& Calmont, S., 1995: Geodetic observations of very rapid convergence and back-arc extension at the Tonga arc. Nature 374: 249-251.

Bradley, W.C. \& Griggs, G.B., 1976: Form, genesis and deformation of central Californian wave-cut platforms. Geol. Soc. Am. Bull. 87: 433-449.

Coffin, M.F., Karner, G.D. \& Falvey, D.A., 1994: Research cruise yields new details of Macquarie Ridge Complex. EOS, Trans. Am. Geophys. Union 75(48): 561, 564

Colhoun, E.A. \& Goede, A., 1973: Fossil penguin bones, ${ }^{14} \mathrm{C}$ dates and the raised marine terrace of Macquarie Island: some comments. Search 4: 499-501.

Colhoun, E.A. \& Goede, A., 1974: A reconnaissance survey of the glaciation of Macquarie Island. Pap. Proc. R. Soc. Tasm. 108: 1-19

Collot, J-Y., Delteil, J., Herzer, R.H., Wood, R., Lewis, K.B. \& Shipboard Party, 1995: Sonic imaging reveals new plate boundary structures offshore New Zealand. EOS, Trans. Am. Geophys. Union 76(1): 1, 4, 5.

Cox, A \& Embretson, D., 1985: Change in plate motion of the Pacific plate at 5 Myr BP. Nature 313: 472-474.

CROHN, P.W., 1986: THE GEOLOGY AND GEOMORPHOLOGY OF MACQUARIE ISLAND WITH SPECIAL EMPHASIS ON HEAVY METAL TRACE ELEMENT DISTRIBUTION. ANARE Res. Note 39: $28 \mathrm{pp}$.

Division of National Mapping, 1971: MACQUARIE ISLAND, TASMANIA. 1:50,000 Topographic Map. Department of National Development, Canberra, Australia.

Duncan, R.A. \& VARNe, R., 1988: The age and distribution of the igneous rocks of Macquarie Island. Pap. Proc. R. Soc. Tasm. 122(1): 45-50.

Gordon, A.L., 1972: On the interaction of the Antactic Circumpolar Current and the Macquarie Ridge. In Hayes, D.E. (Ed.): ANTARCTIC OCEANOGRAPHY, THE AUSTRALIAN-NEW ZEALAND SECTOR. Am. Geophys. Union, Antarct. Res. Ser. 19: 71-78.

Guérin, G. \& Balladas, G. 1980: Thermoluminescence dating of volcanic plagioclases. Nature 286: 697-699.

Harbert, W. \& COX, A., 1989: Late Neogene motion of the Pacific plate. J. Geophys. Res. 94(B3): 3052-3064.

Herzig, P., Hannington, P., McInnes, B., Stoffers, P., Villinger, H., Seifert, R., Binns, R. \& Liebe, T., 1994 : Submarine volcanism and hydrothermal venting studied in Papua New Guinea. EOS, Trans. Am. Geophys. Union 75(44): 513, 515, 516.

Imbrie, J., Hays, J.D., Martinson, D.G., Mcintyre, A., Mix, A.C., Morley, J.J., Pisias, N.G. Prell, W.L. \& SHACKLeTON, N.J., 1984: The orbital theory of Pleistocene 
climate: support from a revised chronology of the marine $\delta 18$ O record. In Berger, A.L. et al. (Eds): MILANKOVICH AND CLIMATE, Part I. D. Reidel Publishing Company, Dordrecht: 269-305.

JONES, T.D. \& MCCUE, K.F., 1988: The seismicity and rectonics of the Macquarie Ridge. Pap. Proc. R. Soc. Tasm. 122(1): $51-57$.

Kamp, P.J.J., Green, P.F. \& White, S.H., 1989: Fission track analysis reveals character of collision tectonics in New Zealand. Tectonics 8: 169-195.

Kamp, P.J.J., Green, P.F. \& Tippett, J.M., 1992: Tectonic architecture of the mountain front-foreland basin transition, South Island, New Zealand, assessed by fission track analysis. Tectonics 11: 98-113.

Ledingham, R. \& Peterson, J.A., 1984: Raised beach deposits and the distribution of structural lineaments on Macquarie Island. Pap. Proc. R. Soc. Tasm. 118: 223-235.

LOffler, E. \& Sullivan, M.E., 1980: The extent of former glaciation on Macquarie Island. Search 11: 246-247.

MAWSON, D., 1943: MACQUARIE ISLAND: ITS GEOGRAPHY AND GEOLOGY. Australas. Antarct. Exped. 1911-14, Sci. Reps Ser. A: 5

MCINELLY, G.W. \& Kel.SEY, H.M., 1990: Late Quaternary tectonic deformation in the Cape Arago-Bandon region of coastal Oregon as deduced from wave-cur platforms. J. Geophys. Res. 95(B5): 6699-6713.

Muhs, D.R., Kelsey, H.M., Miller, G.H., Kennedy, G.L., WhELAN, J.F. \& MCINELLY, G.W., 1990: Age estimates and uplift rates for Late Pleistocene marine terraces: southern Oregon portion of the Cascadia fore-arc. J. Geophys. Res. 95(B5): 6685-6698.

Pollitz, F.F., 1986: Pliocene change in Pacific-plate motion. Nature 320: 738-741.
RufF, L.J., 1990: The great Macquarie Ridge earthquake of 1989: Introduction. Geophys. Res. Lett. 17: 989-991.

Selxirk, D.R., Selkirk, P.M. \& Griffin, K., 1983: Palynological evidence for Holocene environmental change and uplift on Wireless Hill, Macquarie Island. Proc. Linn. Soc. NSW 107: 1-17.

Selxirk, P.M. \& Adamson, D.A., 1995: Mapping Macquarie Island. The Globe. J. Aust. Map. Circle 41: 53-67.

Selkirk, P.M., Adamson, D.A. \& WiLson, M.E., 1990a: Raised marine terrace on north-west coast of Macquarie Island. Proc. Linn. Soc. NSW 112: 141-146.

Selkirk, P.M., Seppelt, R.D. \& Selkirk, D.R., 1990b: SUBANTARCTIC MACQUARIE ISLAND: ENVIRONMENT AND BIOLOGY. Cambridge University Press, Cambridge: $285 \mathrm{pp}$.

Taylor, B., Goodliffe, A., Martinez, F. \& Hey, R., 1995: Continental rifting and initial sea-floor spreading in the Woodlark Basin. Nature 374: 534-537.

Varne, R. \& Rubenach, M.J., 1972: Geology of Macquarie Island and its relationship to oceanic crust. In Hayes, D.E. (Ed.): ANTARCTIC OCEANOLOGY II, THE AUSTRALIAN-NEW ZEALAND SECTOR. Am. Geophys. Union, Antarct. Res. Ser. 19: 251-266.

Varne, R., Gee, R.D. \& Quilty, P.G., 1969: Macquarie Island and the cause of oceanic linear magnetic anomalies. Science 166: 230-232.

Weissel, J.K., Taylor, B. \& Karner, G.D., 1982: The opening of the Woodlark Basin, subduction of the Woodlark spreading system, and the evolution of northern Melanesia since mid-Pliocene time. Tectonophysics 87: 253-277.

(accepted 14 May 1996) 